\title{
EVALUATION APPROACH ON PUBLIC-PRIVATE PARTNERSHIP (PPP) URBAN REDEVELOPMENTS
}

\author{
Barbara Y. P. LEUNG and Eddie C. M. HUI \\ Department of Building and Real Estate, The Hong Kong Polytechnic University, Hung Hom, Kowloon, \\ Hong Kong, China \\ Fax: (852) 2764 5131, E-mail: bsbleung@polyu.edu.hk, bscmhui@polyu.edu.hk
}

Received 26 August 2004; accepted 22 January 2005

\begin{abstract}
Urban redevelopments in recent years tend to follow a pragmatic market-led partnership approach with involvement of both public and private sectors. However, it has been evidenced that this approach suffers from a number of deficiencies. These include over-reliance on private investments which make the project vulnerable to financial risks and over-emphases on creating a place of opportunity rather than improving the social environment in the deprived areas. This paper proposes an approach encompassing Cost-Benefit Analysis (CBA) and Option Pricing concepts (OP) into urban renewal projects which is considered more appropriate for urban redevelopment appraisal. The approach is applied for appraising the bust-boom saga of the London Docklands redevelopment to demonstrate the importance of the inclusion of social costs and benefits in the evaluation and the strategic value of operating options. Furthermore, key factors for an urban redevelopment project are also identified from the analyses which are considered crucial for the success of the project.
\end{abstract}

KEYWORDS: Public-Private Partnership; Cost-Benefit Analysis; Option Pricing; Urban redevelopment; London Docklands

\section{INTRODUCTION}

Since the deregulation of financial markets and the adoption of laissez-faire approach in many countries in the early 1980 s, urban redevelopment projects undertaken by public sectors have adopted a market-led strategy with the involvement of private sectors. The strategy, in form of Public-Private Partnership (PPP), is not limited to real estate projects. A wide range of public and social infrastructure have been built and public services delivered through this approach which include the management of the Government PRIME Estate in the United Kingdom, the construction and maintenance of the County Court Complex in Melbourne of Australia and the redevelopment of Melbourne Docklands (HKSAR 2001). The advantages of PPP are to bring together the complementary skills of both public and pri- vate sectors to the completion of a project, with varying levels of involvement and responsibility. According to the "Building Better Partnership" report published by the Institute of Public Policy in 2002 in the UK, projects which adopted a PPP approach achieved high quality production with innovative design and improved working environments. Surveys also indicated that savings ranging from $2 \%$ to $17 \%$ were realized in some projects (HKSAR 2001).

Despite the advantages brought, urban redevelopment projects adopting a market-led approach are not without problems. Very often, business interests dominate the negotiations between the authority and the private sector. Moreover, the appraisal methods adopted in private markets, which include investment method and residual method, often fail to take adequate consideration of social costs and benefits of an urban redevelopment 
(Scarett 1991). Furthermore, these methods ignore the very important characteristics of a land and property redevelopment (Leung \& Hui 2000). Firstly, property redevelopments are mostly economically irreversible. Once a piece of land is redeveloped, the property outlay will freeze the land into a particular use and fix for a long time the services that the property will render. Therefore, irreversibility makes investment especially sensitive to uncertainty over the future market condition such as changes in operating cost, volatility of demand and competitive interaction. The second characteristic is the sequential nature of a land redevelopment project. As investment decisions and associated investment outlays occur sequentially during the redevelopment process, the timing of the construction layers including both the infrastructure and the superstructure and the arrival of new information will certainly be crucial to the developer to continuously improve the decision-making at different stages of a redevelopment (Pindyck 1991).

Since urban redevelopments are irreversible, an appraisal method that can measure the relevant costs and benefits accurately and can identify strategic flexibilities is crucial for the success. For large and complex public projects like the London's Docklands in which price signals of "public goods" are inadequate to guide investment decisions and 'spillover' benefits and costs are important, the use of Cost-BenefitAnalysis (CBA) seems a more appropriate method for evaluation purpose (Harvey 2000). Furthermore, not all redevelopment projects can be run as smoothly as they were planned because of the existence of uncertainty during the long construction period. Encompassing the Option Pricing concepts (OP) into the CBA framework can improve the capital budgeting and capture the operational flexibilities of a project. It also gives the developer an option to revise his decision in response to unexpected market changes.

This paper attempts to apply the framework encompassing the CBA and OP to assess the bust-boom redevelopment of the London's
Docklands, and aims at identifying the key factors that would lead to the success of urban redevelopments adopting a PPP approach. The study is of significance as many of the onceprosperous districts in many cities have grown "out-dated" with problems of poverty, dilapidated buildings and unemployment which typically need regeneration. Examples include the recent redevelopment of Melbourne's Docklands in Australia, Dublin's Docklands in Ireland and London's Docklands in the UK. Though the regeneration of the London's Docklands was completed in the late $1990 \mathrm{~s}$, the size and its significance, and the problems it had gone through under the market-let approach have set good lessons for practitioners to learn.

The content of this paper is arranged as follows: Section 2 provides the research background on the evaluation approach adopted for appraising urban redevelopments. Section 3 proposes a hybrid urban redevelopment appraisal method encompassing the CBA and OP concepts which is considered more appropriate for appraising urban redevelopment projects. The London Docklands regeneration is illustrated in Section 4 as a case-study to identify the problems within the redevelopment process and the possible operation flexibilities that can be embedded based on the hybrid appraisal method. A number of key success factors have also been identified in Section 5 for a successful urban redevelopment project.

\section{RESEARCH BACKGROUND}

Previous studies of urban redevelopment had largely focused on social aspects and spatial-structural analysis rather than on privatesector decision making. Until recent years, there has been increasing discussions focusing on the political-economic analysis of the different roles played by public and private sectors in urban redevelopment following the increasing use of market-led PPP approach (Fainstein 2001). As regards the arrangement of PPP, public sectors become more involved as regulators and procurers of the projects rather than 
as direct providers of services to the public. Their fundamental role is to set the objectives and timeframe and act as the promoter. They set the broad context of the scheme and leave as much flexibility as possible so that plans within the scheme can be tailored by the private developers according to the specific needs of the local districts. As such, public sectors can transfer certain risks specific to construction market, which include technical risk of construction, operation risk, financial and market risk, to private sectors (Leung 2003). Private developers will receive the rewards that are commensurate with the amount of risks to be borne.

However, execution of urban redevelopment adopting a market-led approach is not without problems. Business interests often dominate the negotiations between the authorities and the private sectors in projects such as the redevelopment of Battery Park City in New York (Fainstein 2001), the Docklands redevelopment in Melbourne (Long 1998) and the London's Docklands in the UK (Brownill 1990 and 1999). Market-led developers sought improvements of the areas through the provision of attractive and centrally-located housing and the related facilities favouring middle-class consumers. Low-income inhabitants faced the result of rising living expenses and breaking up of the community, and some were even forced out of the areas to give space for the redevelopment. As a consequence, researchers started to connect urban redevelopment policy with the social and economic factors which form the basis for the studies on urban redevelopment economics and finance (Cullingworth 1971, Brownill 1999, Fainstein 2001).

The most commonly used appraisal method in evaluating public projects is CBA in which the welfare of local residents and future generations can be allowed for. It does this by identifying all the relevant benefits and costs of a particular scheme and quantifying them in money terms so that each can be aggregated and then compared. CBA has been around for a long time, and started to be applied in gov- ernment projects since 1940s after Vilfredo Pareto refined the CBA concepts in defining social improvements (Merewitz 1973). However, difficulties are found to apply CBA in urban redevelopment projects when PPP is involved. It has been evidenced that the social aspects of the projects are often ignored by private partners (Long 1998, Brownill 1999, Fainstein 2001). Furthermore, the costs against benefits yielded are often measured with bias by the promoters, both the public and private, of the project. Flyvbjerg et al. (2002) has carried out a research on the use of CBA in 258 infrastructure and land development projects and found that the costs are often underestimated and it can be explained from four aspects, i.e., technical, economic, psychological and political.

Technical - Technical problems of the forecasting techniques, such as the use of imperfect estimation model, inadequate data, and the lack of experience on the part of forecasters (Ascher 1978; Morris \& Hough 1987).

Economic - The estimation of the costs may be affected by the economic self-interest of the project promoters who try to make the project looks attractive by keeping the cost low (Merewitz 1973).

Psychological - Project promoters are often described as "empire builders" who are engineers like to build big things (Flyvbjerg et al 2002). With this inherent mentality, they tend to be over-optimistic about the project outcomes in their appraisal.

Political - When a project has a political content, its forecasts are intentionally biased to serve the interests of project promoters in getting the project started. The assumptions are often made based on an ideal world according to plan, with no delay, no changes in safety and environmental performance specifications, no management problems, no problems with contractual arrangements and new technologies, etc. An example is the built of the Eurotunnel in which the final cost was almost twice of the forecast (World Bank 1994).

In fact, the real world is embedded with 
numerous uncertainties. Other than avoiding the technical problems and promoters' influence to the project, the use of OP concepts, which can capture the operating flexibilities embedded in the project in form of "real options", can help mitigate the loss arisen from uncertainties and the limitation of CBA (Kester 1984, Trigeorgis 1996). Shoup (1970) worked on the timing option of an urban land development project whereas Capozza and Sick (1992) examined the value of the option to redevelop a property. Roberts and Weitzman (1981) attempted to examine projects with sequential investment outlays using a model that stresses the role of information gathering. Leung and Hui (2000 and 2002) expanded the application of the Option Pricing Theory (OP) to the valuation of property development projects by integrating both the capital budgeting and the strategic planning. In their models, each stage of investment yields information that reduces the uncertainty over the value of the completed project. The developer may, therefore, revise the spending scenario originally planned in different stages in response to the new market condition.

\section{HYBRID REDEVELOPMENT APPRAISAL METHOD}

This section attempts to encompass both CBA and OP for developing a hybrid appraisal method which is considered appropriate for the evaluation of urban redevelopment projects. CBA is an appraisal technique which seeks to bring greater objectivity into decision-making by identifying all the relevant benefits and costs of a particular scheme and quantifying them in money terms so that each can be aggregated and compared (Harvey 2000). To identify the relevant cost and benefit items embedded in an urban redevelopment project is of no-easy task because of its complexity and long project timescale, in particular, when social costs and benefits are involved. It is important to examine the redevelopment process in order to identify the benefits and explore the operating flexibilities inherent in order to set off the costs and hedge against the potential risks that may arise. In general, a redevelopment process can be broken down in the following stages (Goodchild and Munton 1986):

(i) The initial stage - At this stage when the circumstances for a redevelopment are possible, the estimation of the costs on collecting the land, building the necessary infrastructure and superstructure as well as cost on financing should have been prepared. The disturbances to people living in the area and the damages caused to the environment must also be addressed. The gains from the redevelopment which include the revenue from tax and tolls, sale of developable land to private developers and the social welfare yielded to the local community are also estimated.

(ii) Collection of land and construction of infrastructure - The next stage is the collection of land and the construction of the necessary infrastructure to turn the land into developable and accessible forms which include the building of roads, rails and others.

(iii) Construction of the superstructure - It involves the construction of the superstructure according to the redevelopment scheme and the provision of the necessary facilities to meet the needs of the community.

(iv) Release of the properties to the occupants.

In any redevelopment project, no matter how carefully-planned a CBA is at the initial stage, progress could be hindered between stages within the process due to unforeseeable future market behaviours and technical problems. In a changing environment, the decisions in timing the redevelopment are important. Developers need to ensure that the requirements for the economic development and the infrastructure will be ready upon the completion of the redevelopment scheme (Capozza \& Sick 1992, Quigg 1993). Furthermore, the value of a project may derive not just from its expected directly measurable 
cashflows, but also from unlocking the growth path of future opportunity (Kester 1984). Based on these reasons, it would be more preferable if the project could start up in a small scale but with more expansive construction mix for the built-in flexibility to expand the redevelopment if and when desirable. On the other hand, a project would be more valuable if it is equipped with an option to contract or defer. For example, if the redevelopment is arranged into phases, it would be easier in contracting the scale or deferring part of the construction if the market condition turns out to be weaker than originally expected. The flexibility that can facilitate switching of the use of the property is also of value. If the demand for com- mercial property suffers a sustained decline, the developer may decide to switch it into the best alternative use.

Figure 1 proposes a more appropriate method for appraising urban redevelopment by encompassing the concepts of CBA and OP into the redevelopment process. With this approach, any possible flexibility can be captured to reflect the potential of the project and the relevant costs and benefits can also be more accurately identified and evaluated. In the following section, the regeneration of the London's Docklands will be examined to identify where the problems were and how the risks could be mitigated based on the hybrid appraisal method developed.

\section{Redevelopment Process}

a. Initial stage

- costs on turning the area into developable land and building the infrastructure

- costs on financing for the projects

- costs on the environment and the welfare of the local community

- revenues from tax and tolls from transport users

- income from sale of land to private developers

- income from joint redevelopment partnering with other sectors

- benefits yielded to local community as a result of the redevelopment which include the provision of housing, employment, recreational facilities and etc.

b. Collection of land and construction of the infrastructure

- timing of land and transport infrastructure redevelopments is important

- keep the option to expand or defer the redevelopment depending on the requirements of the environment

c. Construction of the superstructure

- superstructure redevelopment can be separated into phases

- project should be kept small in the first phase but with more expensive construction mix so that the redevelopment can be expanded if and when desirable

- operation flexibility to contract the project should be installed which enables the project to be scaled down or deferred if the market condition turns out to be weaker than originally expected

d. Release of the properties and facilities to occupants

- flexibility should be installed to switch the use of the property to its best alternative use if an adverse environment is encountered

Figure 1. Hybrid Urban Redevelopment Appraisal Method 


\section{THE LONDON DOCKLANDS REGENERATION}

The London's Docklands was built in the early 1900s. It, however, could not keep up with its competitors as a result of new technology and containerisation and had turned into a barren and derelict wasteland in the second half of last century. Nevertheless, because of its proximity to London City, it was the desirable area for expansion to ease the congestion of Inner London (Brownill 1999). The redevelopment started in the 1970s which covered a total of eight-and-a-half square miles stretching across parts of the five Docklands boroughs along the Thames River which include Wapping, Limehouse, Surrey Docks, Isle of Dogs, Royal Docks and Beckton as shown in the Map contained in the Appendix. The scope of the project was vast which aimed at creating a place with opportunities, attractive environment, the provision of housing and social facilities for people to live and work at (LDDC 1998e).

By the end of 1998 upon the completion of the regeneration, the Docklands was turned into an attractive metropolitan city with population doubled and the unemployment rate was greatly reduced (see Table 1 ). $25 \mathrm{~m} \mathrm{ft}^{2}$ of commercial space were built in the Docklands and 24,000 residential units were constructed. However, the project was not without difficulties throughout the two decades of regeneration. Local influence and opposition, changes in central government policy and economic environment had caused much trouble to the process. This study attempts to divide the redevelopment process of the London Docklands into different stages with reference to the hybrid method presented in order to identify the problem areas and look for means for rectification for future projects.

\subsection{The Initial Stage - Priming the Pump}

In the planning stage, the Docklands Joint Committee (DJC) was established in 1974 to prepare the strategic plan for the redevelopment. The DJC considered that a market-led approach was appropriate in which the market was to determine what should be built and where it should be built. It aimed at creating the circumstances in which private investment would fund the economic regeneration of the place, while at the same time to improve its social infrastructure and public amenities (LDDC 1998b). Therefore, the plan had been made flexible and provided scope and options for enterprise initiatives for the coming redevelopment.

Regarding the funding, the DJC's approach was to 'prime the pump' of the redevelopment through the so called 'leverage planning', i.e. the use of public investment in infrastructure to stimulate the private market in the land and property redevelopment. Other than the construction package of $£ 17 \mathrm{~m}$ announced in 1977 budget to kick-off the project, the then Secretary of State for Environment, Peter Shore,

Table 1. Docklands before and after the LDDC

\begin{tabular}{lll}
\hline & 1981 & 1998 \\
\hline Population & 39,400 & 81,231 \\
Employees & 27,200 & 85,000 \\
Home ownership & $5 \%$ & $45 \%$ \\
Dwelling stock & 15,000 & 38,665 \\
Service sector employment & $31 \%$ & $70 \%$ \\
Financial services employment & $5 \%$ & $43 \%$ \\
Commercial floorspace since 1981 & & $25 \mathrm{ft}^{2}$ \\
Housing units built since 1981 & $17.8 \%$ & 24,042 \\
Unemployment rate & $7.2 \%$ \\
\hline
\end{tabular}

Source: Various Monographs of London Docklands Development, LDDC, 1998. 
had made it clear that the redevelopment in the Docklands would only be eligible for the normal forms of Government financial support to transport, housing and other purposes. The Government had no plans for special forms of support over and beyond these. Therefore, although general planning on the infrastructure had been carried out in the initial stage, no identified routes and no decision was taken on the provision of the spinal public transport to link the Docklands and the areas outside, nor any consideration on the social needs. These led to serious underestimations of the final costs spent on both the transport and the social infrastructure required in the areas.

To induce private investment, Isle of Dogs was assigned as the Enterprise Zone and a number of incentives were offered to private developers. They included exemption of Development Land Tax and the right to offset $100 \%$ of the investment against future tax for ten years, and the sites were sold at a price well below the value of the publicly financed works to benefit private developers. The 'leverage planning' was considered successful at the early stage as, by $1988, £ 441$ m of public money had 'levered' $£ 4,440$ m of private investment, which was achieved largely at the expense of the tax concessions.

\subsection{The Preparation of Transport and Community Infrastructure}

At the start of the redevelopment, the DJC kick-started the infrastructure programme with the filling of 120 acres of dock basins at a cost over $£ 10 \mathrm{~m}$. A road programme and a housing programme had also commenced to facilitate the creation of the new redevelopment zone, however, these were all small beginnings and little progress had been made on the major transport proposals. The slow progress of the redevelopment was attributed partly to the limit of capital funded by the government. Also, some $80 \%$ of all land was in the ownership of local authorities and utility companies which had later seriously frustrated the land assem- bly process (LDDC 1998b). To resolve the problems, the London Docklands Development Corporation (LDDC) was set up in 1981 empowered with land acquisition powers. It also acted as the promoter and a single development control planning authority to provide a 'one-stop service' for investors and developers seeking advice and planning permission. Although financial support was further secured from the Treasury to receive $£ 60 \mathrm{~m}$ every year for the redevelopment, the costs of the transport and infrastructure required for just converting the Canary Wharf within the Enterprise Zone into an office center was far much greater than the fund provided. By 1986, only a two-lane road across the north of the Enterprise Zone had been completed, the rail construction was halted and the value of major roads still committed for the area was reduced to about one tenth of what had been proposed. The timing of the transport infrastructure construction and the superstructure redevelopment were totally unmatched. The option to defer the superstructure redevelopment in matching the construction of the transport system should have been considered by the private developers when the development went along.

As regards the social infrastructure, the LDDC considered itself a marketing agency selling development land rather than overseeing the rehabilitation of an area over 40,000 inhabitants. Little consultation had been made on the needs of the local authorities who were expecting that the programme would help rehouse the tenants in new houses with gardens. As a result, only 2,398 new homes had been built in the Docklands from 1976 to 1985 , compared with a target of 6000 for 1982 . As regards the employment, over 8,500 jobs had been lost in the five years since 1976 and less than 800 new jobs were created during the same period. This compared with the Plan's target of 12,000 new jobs to be created by 1982 . As a result, local councils opposed to the new venture and were reluctant to make concessions for achieving the integrated regeneration. 


\subsection{The Property Development in Full Scale Before 1992}

Perhaps the most important underlying factor behind the extravagant redevelopment programmes of the Docklands was the economic boom experienced in the UK between 1984 to 1988 with property prices soared by $128 \%$. Without having careful strategic planning and considerations, developers urged to get a kick-start at the same time fearing that any delay would pull them off the profit ladder. The property market in the Enterprise Zone by then was strongly supply-led with the belief that the large quantities of new offices built would be fully occupied within two years of completion. With the joining of Olympia \& York (O\&Y) in 1986, one of the world's largest development companies, the LDDC agreed with the proposed expanded redevelopment from the original of $8 \mathrm{~m} \mathrm{ft}^{2}$ commercial floorspace to $12 \mathrm{~m}$ $\mathrm{ft}^{2}$. As a result, over $21 \mathrm{~m} \mathrm{\textrm {ft } ^ { 2 }}$ of commercial space were built from the start of the project up to 1992 (Table 2). Among them, nearly 30\% were completed in 1992 , over $78 \%$ were completed within the four years from 1989 to 1992 .
The extended scale of the project meant that transport infrastructure and services would have to be upgraded when the area reached its full scale of operation. As early as 1989, the East London Rail observed the problem and made the recommendation of the construction of a large-scale extension of the Jubilee Line in the underground railway system, the upgrading of arterial roads, and the provision of a Docklands Light Railway (DLR). However, the total costs of completing these projects were estimated to involve $£ 100 \mathrm{~m}$ of private capital, $£ 80 \mathrm{~m}$ of bank loans and $£ 220 \mathrm{~m}$ of public funds. Though finance was secured from O\&Y, substantial time was required to complete the transport infrastructure. As a result, the transport of the Docklands was below the envisaged level upon the completion of the buildings during the years 1989-1992, and was totally inadequate to cope with the operation of the London's Docklands. If developers would have considered the option to divide the developments into stages and to start up the project with a smaller scale, and then to expand the development in pace with the economic envi-

Table 2. New Commercial and Industrial Floorspace 1982 - 1998

\begin{tabular}{|c|c|c|}
\hline Year & $\begin{array}{l}\text { Annual } \\
\left(\text { Million } \mathrm{ft}^{2}\right)\end{array}$ & $\begin{array}{l}\text { Cumulative } \\
\left(\text { Million } \mathrm{ft}^{2} \text { ) }\right.\end{array}$ \\
\hline 1982 & 0.215 & 0.22 \\
\hline 1983 & 0.215 & 0.43 \\
\hline 1984 & 1.291 & 1.72 \\
\hline 1985 & 0.215 & 1.94 \\
\hline 1986 & 1.829 & 3.77 \\
\hline 1987 & 0.861 & 4.63 \\
\hline 1988 & 0.646 & 5.27 \\
\hline 1989 & 3.443 & 8.72 \\
\hline 1990 & 3.120 & 11.84 \\
\hline 1991 & 2.905 & 14.74 \\
\hline 1992 & 6.994 & 21.74 \\
\hline 1993 & 1.937 & 23.67 \\
\hline 1994 & 0.430 & 24.10 \\
\hline 1995 & 0.215 & 24.32 \\
\hline 1996 & 0.215 & 24.53 \\
\hline 1997 & 0.215 & 24.75 \\
\hline 1998 & 0.323 & 25.07 \\
\hline
\end{tabular}

Source: LDDC 1998c. 
ronment, the negative impact from the mismatch of timing would have been mitigated.

\subsection{The Downturn of the Redevelopment After 1992}

With the downfall of the economy during the first half of the 1990s and the failure of the government to provide the necessary infrastructure including the transportation and social amenities, there was a significant decline on the demand for commercial space, in particular, the Docklands was considered only secondary to London City. Between 1988 and 1994, the property prices fell by $43 \%$ and $45 \%$ of Docklands' office space was vacant. Furthermore, when the major construction was finalized with the joining of O\&Y in the years between 1987 and 1989, interest rates were comparatively low at $9 \%$ and inflation at some $4 \%$ annually. By 1991, interest rates rose to $15 \%$ and inflation exceeded $8 \%$. These had exacerbated the impact of the recession struck after 1990. As the real estate crisis worsened, major developers found themselves in increasing financial difficulty. Developers like Godfrey Bradman of Rosehaugh PLC took their option to default on their loans. Most serious of all was the crumbling of O\&Y empire and the Canary Wharf redevelopment was taken into administration in 1992. If the private developers would have arranged the construction into phases and to allow for the option to contract, they could have downsized the scale of the redevelopment when the market condition changed. Otherwise, switching part of the redevelopment into its best alternative use was another option in order to mitigate the loss, as some of the developers had converted part of the floorspace into service apartments.

On the social aspect, the LDDC was criticized in the Parliamentary report for the lack of social investment in the project. The situation was exacerbated during the early 1990s as the receipt from land sales dropped substantially from a predicted $£ 130 \mathrm{~m}$ in 1989 to $£ 10 \mathrm{~m}$ in 1990. Therefore, most programmes were kept below their original estimates except housing. Also, private developers were so aghast at the social mess in the area and stated that not only was a skilled and trained workforce important for the commercial viability of schemes but so was a neighbourhood free of social conflict. As a result, a Memorandum was made with the local authorities to include the construction of social housing in the area, community facilities and a structure for consultation.

\subsection{Revival and the Release of the Redevelopment from the LDDC}

By March 1993, the administrator was able to present a workable plan characterized by a 14-year restructured cashflow programme. The government also agreed to provide $£ 1600 \mathrm{~m}$ to improve the transportation. With the improvement of the national economy, the Enterprise Zone became active again when the Canary Wharf project was bought over by the International Property Consortium (IPC) at a fraction of its costs of construction in 1995 (Pugh 1996).

However, the favourable economic conditions in the mid-1990s did not produce wild speculative activities in the Docklands' property market but proceeded in response to demand. By learning from the past, bankers and lenders scrutinized projects more carefully and required developers to put substantial amounts of their own funds into their projects before the loans were granted. As a consequence of relatively little growth in supply, rent levels recovered strongly at an average growth of $6 \%$ in the second half of the 1990s. Until 1998, a total of $25 \mathrm{~m} \mathrm{ft}{ }^{2}$ commercial space had been built and over 24,000 housing units were constructed. It also marked the completion of the regeneration of the Docklands with the closure of the LDDC in March 1998. With the improvement of the economy and the property market in the late Nineties, $98 \%$ of the office space were let out and property prices had gone up by $30 \%$. 


\subsection{Summary of the Lessons Learnt in the Docklands Redevelopment}

To review the London Docklands' regeneration, the costs of the project were found huge. The LDDC claimed that the project was successful as the $£ 1,860 \mathrm{~m}$ government grant allotted was able to induce $£ 7,200 \mathrm{~m}$ of private investment to turn the Docklands into an attractive city in the world. However, it was estimated that the costs incurred, including those supported by other public sectors like London Transport, had added up to a total of nearly $£ 6,000$ m (Table 3 ), which had far exceeded the government grant allotted. This had not included the hidden subsidies granted in form of tax incentives and the capital allowances and the discount offered on land sales. Critics also pointed out that the revenue loss just on the financial incentives given was estimated at $£ 1,000 \mathrm{~m}$ (Observer 1994). To sum up, the project had incurred a total cost of, including both actual and hidden, over $£ 7000$ m of public money. As such, Brownill depicted the Docklands case as a typical example of "reverse leverage", where the private sector secured public underwriting of its investment, than the pump-priming envisaged in the early days.

As regards the social infrastructure, after the Memorandum was issued in 1989, the community team within the LDDC initiated a programme which encompassed education and training projects, health centre provision and social service ambitions. Although many improvements have been achieved in the area, the investment vested in improving the welfare of the local communities, including both social housing and community \& industry support, was still limited which represented less than $5 \%$ of the total public expenditure (Table 3 ). Figure 2 summarises the major problems identified in each stage of London's Docklands redevelopment and the possible operation flexibilities which could have been embedded using the CBA and OP concepts.

Table 3. Public Expenditure for London Docklands Regeneration

\begin{tabular}{|c|c|c|}
\hline Expenditure & $£(m)$ & $f(m)$ \\
\hline \multicolumn{3}{|l|}{ Transportation Schemes: } \\
\hline Roads in Dockland ${ }^{1}$ & 570 & \\
\hline Roads to Dockland ${ }^{2}$ & 841 & \\
\hline Dockland Light Railway $^{3}$ & 684 & \\
\hline Underground $^{3}$ & 2365 & \\
\hline Other minor transport schemes & 45 & \\
\hline Sub-total & & 4505 \\
\hline \multicolumn{3}{|l|}{ Other Expenses ${ }^{4}$ : } \\
\hline Land Acquisition & 187 & \\
\hline Land Reclamation & 157 & \\
\hline Utilities & 159 & \\
\hline Environmental & 149 & \\
\hline Social Housing & 163 & \\
\hline Community and Industry Support & 117 & \\
\hline Promotion and Publicity & 27 & \\
\hline Administration and Maintenance & $\underline{261}$ & \\
\hline Sub-total & & $\underline{1220}$ \\
\hline TOTAL EXPENDITURE & & $\overline{5725}$ \\
\hline
\end{tabular}

Sources: LDDC 1997b, Brownill 1999.

1 Supported by LDDC

2 Supported by Department of Transport and Private Finance Initiative

3 Supported by LDDC and London Transport

${ }^{4}$ Supported by LDDC 


\begin{tabular}{|c|c|}
\hline \multicolumn{2}{|c|}{ Redevelopment Process } \\
\hline Lessons learnt from the redevelopment: & Options available: \\
\hline $\begin{array}{l}\text { a. Initial stage } \\
\text { - underestimated the costs of land infrastructure and } \\
\text { the transport system } \\
\text { - land prices were set too low to off-set the } \\
\text { necessary expenses } \\
\text { - ignorance on the social needs }\end{array}$ & $\begin{array}{l}\text { - option to expand the size of } \\
\text { redevelopment embedded in early } \\
\text { planning, e.g. the capacity of utility } \\
\text { facilities }\end{array}$ \\
\hline $\begin{array}{l}\text { b. Collection of land and construction of the } \\
\text { infrastructure } \\
\text { - limited power of DJC on land assembly } \\
\text { - under-commitment of public funding for land and } \\
\text { transport infrastructure } \\
\text { - inadequate attention paid on social infrastructure }\end{array}$ & $\begin{array}{l}\text { - option to defer (part of) the property } \\
\text { development in the planning stage to } \\
\text { allow for the timing of transport } \\
\text { system to match }\end{array}$ \\
\hline $\begin{array}{l}\text { c. Construction of the superstructure } \\
\text { Pre-1992 period } \\
\text { - over-emphasis on supply-led property development } \\
\text { - over-commitment of private funding on the project } \\
\text { through excessive borrowing } \\
\text { - mis-match of timing between the transport infrastructure } \\
\text { and set-off of commercial activities } \\
\text { Post-1992 period } \\
\text { - substantial public funding was injected to complete } \\
\text { the transport system }\end{array}$ & $\begin{array}{l}\text { - property development should be } \\
\text { arranged into stages to allow for the } \\
\text { option to expand or contract in pace } \\
\text { with the demand in the market }\end{array}$ \\
\hline $\begin{array}{l}d . \text { Release of the properties and facilities to occupants } \\
\text { - converted empty office spaces into hotels and apartments } \\
\text { - prudent demand-led property investment policies adopted } \\
\text { by the private sector }\end{array}$ & $\begin{array}{l}\text { - option to switch the vacant offices to } \\
\text { its best alternative use if there is an } \\
\text { over-supply of commercial properties }\end{array}$ \\
\hline
\end{tabular}

Figure 2. Lessons Learnt and Options Available in London Docklands' Regeneration

\section{KEY SUCCESS FACTORS OF URBAN DEVELOPMENTS}

The above analysis of the bust-and-boom of London's Docklands provides us a better understanding on how the evaluation of an urban redevelopment project should take place, more important, it also gives the insight on the several key factors that are indispensable for a smooth operation of the redevelopment and they are elaborated as follows:

Avoid Promoters' Bias in Applying CBA - Promoters of a project tend to, for legal, economic, self-interest and other reasons, underestimate the cost in order to make the proposal attractive to the stakeholders. In the redevelopment of the Enterprise Zone, the aim of the LDDC was the creation of a coherent 
yet distinct district similar to those which constitute in other metropolitan cities. It adopted a "leverage planning" approach hoping to use limited funding from the public sector to stimulate substantial private investment in the area. However, as discussed above, the government eventually needed to spend substantially in the infrastructures and had to go through the troubles caused by the under-commitment and under-funding at the early stage of the project. On the part of the private sector, O\&Y dedicated to build Canary Wharf an office complex more than twice as big as the World Financial Center in New York, with open space, visible fixtures of the highest quality, and buildings equipped with advanced communications technologies. But the costs were huge for such ambitious commitment. The finance was further stretched by the payment of $£ 8.2 \mathrm{~m}$ to settle the land acquired and another $£ 150 \mathrm{~m}$ to support the upgrading of the rail transport. The excessive commitment to the project had brought O\&Y with high risk and huge borrowing and caused it into insolvency when O\&Y was unable to meet the interest obligations on its highly-geared short-term debts when the property market turned into downswing.

To minimize the chance of promoters' bias, a thorough study must be conducted to identify the relevant items relating to the costs and benefits of a project and a third party should be appointed to conduct the feasibility study. Though state-of-art projects are attractive, promoters and developers should strike a balance between the architectural "ideal" and their "bottom line" in order to avoid taking excessive risk and over-commitment.

Balance Private and Social Needs Many recent urban redevelopment projects follow a market-led approach to look for creation of a place of opportunity with improved image and services so that higher income residents would move in. This approach puts much emphasis on the speed of construction in meeting the outputs. However, very often, it has ignored the importance of balancing the social and the private needs of a community. The redevelopment of the Docklands has evidenced that both private developers and local residents were discontented with the lack of social and community facilities in the area and left the social conflicts unresolved during the 1980s. Combined with increasing road traffic congestion, higher house prices, increasing living expenses brought by the redevelopment and loss of land, the local communities became incooperative with the redevelopment considering that others benefited at their expense and, eventually, brought their dissatisfaction to the Parliament. As a compromise, a deal was reached with the local authorities in 1988 for mutually agreed social, economic and community regeneration projects in exchange for cooperation over the construction of the highway schemes in the area (LDDC 1998d).

The study demonstrates that urban redevelopment should take a holistic view by taking consideration of the interaction between economic, communal and ideological forces during the redevelopment process. Furthermore, the planning must be able to cope with the conflicts of different interest groups. As Evans (1971) stated, "It is in the interests of the whole community that the quality of urban living should be improved, and here the public interest is far broader than the immediate private interest, upon which calculations of profitability must be made. It is only a government authority that can effectively weigh the longer-term social implications of creating a better urban environment."

Accessibility of the Development Area - The timing in an urban redevelopment is important in the way that the transport infrastructure must be well in place in order to meet the requirements for the economic development by the time when the commercial activities start to set off. Although substantial planning on transport had been carried out in the initial stage during 1970s, no decision had been taken on the spinal public transport service considered essential to open up the then largely isolated Docklands and to provide reasonable access between Docklands and Central London. 
The lack of certainty in financial planning and the long lead times required for transport schemes had further exacerbated the problem. The lack of transport and the inaccessibility had been a major factor which led to the volatile decline in the demand for Docklands office space in early 1990s. If the developers had calculated more accurately on the needs of transport in line with the increase of commuters and taking the long-lead time of construction into consideration, their losses would, to an extent, have been mitigated.

Embedding Operating Options for Changing Environment Adjustment - In a changing world, the "Everything-Goes-According-to-Plan" approach is too risky in running a project. In any urban redevelopment projects, no matter how carefully-planned a CBA is at the initial stage, progress could be hindered between stages within the process due to unforeseeable future market behaviours and technical problems. Problems may arise due to geotechnical difficulty in preparing the land, the negotiation of the redevelopment scheme and the arrangement of finance. Furthermore, problems may be exacerbated if the CBA is biased by promoters and underestimation of the risks as discussed in the previous sections. Estimation on the costs and benefits based on predictions about the future market behaviour is subject to limited information available at the initial stage. These predictions may not materialise as the project flowing through the events of the development process at varying speeds which are affected by various site factors like adverse weather, skills of labour and more important, political and economic factors of the changing environment. As such, exploration of any embedded options and operational flexibilities which can help to adjust the strategic planning to cope with the changing environment are important to the success of a project.

The massive redevelopment of the Canary Wharf in the later stage could partly be attributed to the flexibility for expansion embedded in the early planning. The original target of the LDDC was to create $8 \mathrm{~m} \mathrm{ft}^{2}$ of commercial space in the Enterprise Zone. Today there are over $25 \mathrm{~m} \mathrm{ft}^{2}$. The rooms allowed for both the upgrading of utility facilities and the provision of developable land in the planning stage had made the expansion of redevelopment possible. Furthermore, the flexibility embedded in the planning permissions within the Enterprise Zone that allowed immediate construction tailored to the needs of the occupying firms, the capacity to build very large floor areas, and the high quality and technological sophistication of the structures had also made the place attractive to developers when the economy started to pick up again.

However, one of the major factors related to the slack demand for Docklands' office space in early 1990s was due to the insufficient transportation to meet the kick-off of the commercial activities. If the developers would have taken the option to defer their construction or part of their construction, and waited for a while for the resolution of the means of transportation, their losses would, to a great extent, have been mitigated. Furthermore, instead of having a kick-start at full scale, the developer may divide the overall development into stages or phases and starts up the project with a smaller scale, but with more expensive builtin construction mix that enable them to expand the development in pace with the economic condition (Figure 2). If the demand for commercial property suffers a sustained decline, the developer may decide to contract the project or switch it into other alternative use. These options are of much value to the overall success of a redevelopment project (Leung and Hui 2002). As seen in the Docklands, many offices had been converted to residential and hotel accommodation which had removed a substantial number of vacant space from the office market coping with the changing environment. These strategic flexibilities can certainly help the project to capture the gain when the economy is favourable and mitigate the loss when the market goes sluggish. 


\section{CONCLUSION}

Many of the large-scale public-funded urban redevelopment schemes following a PPP approach in recent decades have been criticised for being too market-led, with homes built for newcomers or for the benefit of the property developers (Long 1998, Brownill 1999). Furthermore, it has been observed that too little attention has been paid to the social and economic needs of the people living in the deprived neighbourhoods alongside the glittering schemes. This paper, by case-studying the redevelopment of the London's Docklands, has demonstrated that the use of a method encompassing CBA (Cost-Benefit Analysis) and OP (Option Pricing Theory) concepts can be a more appropriate approach to realising the social benefits and costs yielded to the local residents in the appraisal process.

Large-scale urban redevelopment projects involve multiple interests of different parties in planning, mixed-use of redevelopments, the combining of social and physical programming and reliance on private-sector resources and participation. Not all of these complex structured projects can be run as smoothly as it is planned because of the existence of uncertainty arisen from the changing environment during the long construction period. If operation options can be identified and built into different stages of the redevelopment process, then the developer will be able to control the costs and revise the investment strategy by either accelerating or decelerating the rate of investment, in response to the new market condition. By encompassing CBA and OP principles into the redevelopment process, an appraisal method can be developed which is considered more appropriate for the evaluation of an urban renewal project.

Furthermore, key success factors for an urban redevelopment project are also identified as follows:

- avoiding promoters' bias in applying CBA,

- balancing private and social needs,

- accessibility of the redevelopment area,
- avoiding over-capitalised in an upswing market,

- strategic options embedded to adjust for changing environment.

\section{REFERENCES}

Ascher, W. (1978) Forecasting: An Appraisal for Policy-Makers and Planners, Johns Hopkins University Press, Baltimore.

Brownill, S. (1990) Developing London's Docklands, Paul Chapman Publishing, London.

Brownill, S. (1999) Turning the East End into the West End: The Lessons and Legacies of the London Docklands Development Corporation, British Urban Policy: An Evaluation of the Urban Development Corporations, Sage Publications.

Capozza, D. R. \& Sick, G. A. (1992) Valuing LongTerm Leases: The Option to Redevelop. Journal of Real Estate Finance and Economics, 4, p. 209-223.

Cullingworth, J. B. (1971) Urban Renewal: Study No. 3, Centre for Advanced Land Use Studies, College of Estate Management, Edited by A. W. Davidson and J. E. Leonard.

Evans. (1971) Urban Renewal: Study No. 3, Centre for Advanced Land Use Studies, College of Estate Management, Edited by A. W. Davidson and J. E. Leonard.

Fainstein, S. (2001) The City Builders: Property Development in New York and London, 1980-2000.

Flyvbjerg, B., Holm, M. S. \& Buhl, S. (2002) Underestimating Costs in Public Works Projects: Error or Lie? Journal of the American Planning Association, Chicago, Summer 2002.

Goodchild, R. \& Munton, R. (1986) Development and the Landowner: Analysis of the British Experience, Allen and Urwin, London.

Harvey, J. (2000) Urban Land Economics, MacMillan Education Ltd.

HKSAR. (2001) An Introductory Guide to Public Private Partnership, Efficiency Unit, HKSAR.

Kester, W. C. (1984) Today's Options for Tomorrow's Growth. Harvard Business Review, p. 153-169.

LDDC. (1997a) Initiating Urban Changes - London Docklands Before LDDC, Monograph, LDDC.

LDDC. (1997b) Starting from Scratch - The Development of Transport in London Docklands, Monograph, LDDC. 
LDDC. (1998a) Laying the Foundations for Regeneration: Engineering in London Docklands, Monograph, LDDC.

LDDC. (1998b) Regeneration Statement, Monograph, LDDC, March 1998.

LDDC. (1998c) Attracting Investment - Creating Value, Establishing a Property Market in London Docklands, LDDC.

LDDC. (1998d) Learning to Live and Work Together, Monograph, LDDC.

LDDC. (1998e) Housing in the Renewed London Docklands, Monograph, LDDC.

Long, C. (1998) The Melbourne Docklands Redevelopment and the Active Exclusion of the Public, Planning Practice 1998, Australia.

Leung, Y. P. B. (2003) Pricing Model of Risk Premium Embedded in Forward Property Contracts, Proceedings, $31^{\text {st }}$ World Congress, IAHS.

Leung, Y. P. B. \& Hui, C. M. (2000) Real Options Pricing for Property Development. Property Management, 4(1), p. 5-22. (Now known as International Journal of Strategic Property Management).

Leung, Y. P. B. \& Hui, C. M. (2002) Option Pricing for Real Estate Development: Hong Kong Disneyland. Journal of Property Investment \& Finance, 20(6), p. 473-495.

Merewitz, L. (1973) Cost Overruns in Public Works,
Benefit Cost and Policy Analysis, Aldine, Chicago.

Observer. (1994) Feature on London Docklands, 9 October, London.

Morris, P. W. G., and Hough, G. H. (1987) The Anatomy of Major Projects: A Study of the Reality of Project Management, John Wiley and Sons, New York.

Pindyck, R. S. (1991) Irreversibility, Uncertainty, and Investment. Journal of Economic Literature, XXIX, p. 1110-1148.

Pugh, C. (1996) Olympia and York, Canary Wharf and What May Be Learned. Property Management, 14(2), p. 5-18.

Quigg, L. (1993) Empirical Testing of Real OptionPricing Models, The Journal of Finance, XLVIII(2).

Roberts, K., and Weitzman, M. (1981) Funding Criteria for Research, Development, and Exploration Projects. Econometrica, 49(5), p. 12611288.

Scarrett, D. (1991) Property Valuation, E \& F.N. Spon.

Shoup, D. (1970) Optimal Timing of Urban Land Development. Regional Science Association Papers, 25, p. 33-44.

Trigeorgis, L. (1996) Real Options, The MIT Press.

World Bank. (1994) World Development Report 1994: Infrastructure for Development, Oxford Unviersity Press, Oxford.

\section{SANTRAUKA}

\section{VIEŠOSIOS IR PRIVAČIOSIOS PARTNERYSTĖS, RENGIANT URBANISTINIUS PERTVARKYMŲ PROJEKTUS, VERTINIMAS}

\section{Barbara Y. P. LEUNG, Eddie C. M. HUI}

Urbanistiniai pertvarkymai pastaraisiais metais dažniausiai vykdomi laikantis pragmatine rinka pagrịstos partnerystès nuostatos, būdingos tiek viešiesiems, tiek privatiems sektoriams. Tačiau buvo ịrodyta, kad šis būdas turi nemažai trūkumų. Tai susiję su pernelyg dideliu pasitikèjimu privačiomis investicijomis, dèl kurių projektas susiduria su finansine rizika, bei pernelyg pabrěžiamu galimybių sukūrimu, o ne socialinès aplinkos pagerinimu skurdžiuose kvartaluose. Šiame darbe siūloma ị urbanistinius atnaujinimo projektus ịtraukti kaštų ir naudos analizę (CBA) bei pasirinkčių kainodaros (OP) metodiką, kuri laikoma tinkamesne urbanistiniams pertvarkymams ịvertinti. Ši metodika taikoma Londono dokų pertvarkymams vertinti, norint parodyti socialinių kaštų bei naudos įtraukimo ị vertinimą svarbą bei strateginę valdymo pasirinkčių vertę. Be to, pagrindiniai veiksniai urbanistinių pertvarkymų projekte taip pat nustatomi analizès, turinčios esminę įtaką projekto sèkmei, metodu. 


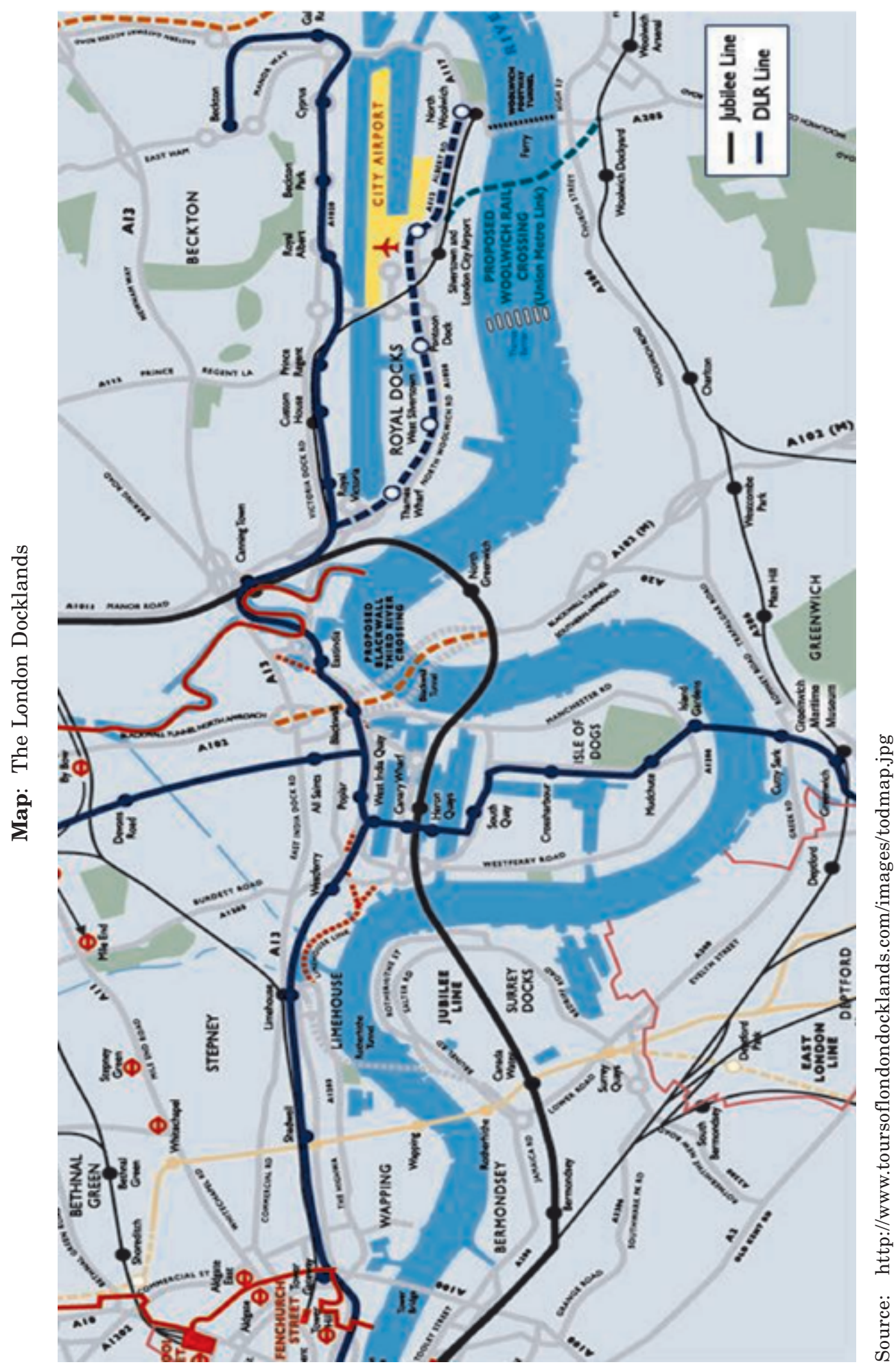

